\title{
PENGARUH PAJAK DAERAH DAN DANA ALOKASI KHUSUS TERHADAP ALOKASI BELANJA DAERAH KABUPATEN MADIUN
}

\author{
Dwi Handayani \\ Elva Nuraina \\ Pendidikan Akuntansi IKIP PGRI MADIUN \\ elvanuraina@yahoo.co.id
}

\begin{abstract}
ABSTRAK
Penelitian ini bertujuan untuk memberikan bukti empiris pengaruh pajak daerah dan dana alokasi khusus terhadap belanja daerah Kabupaten Madiun. Jenis data yang digunakan dalam penelitian ini adalah data primer yang terdiri dari peraturan bupati, Laporan pendapatan asli daerah tahun Laporan Dana Alokasi Khusus tahun dan laporan realisasi anggaran belanja daerah. Metode yang dilakukan dalam penelitian ini adalah metode penelitian kuantitatif dengan menggunakan tehnik analisis regresi linier berganda dan uji hipotesis diolah dengan SPSS. Hasil Analisis data menunjukan bahwa pajak daerah berpengaruh secara positif dan signifikan terhadap alokasi belanja daerah karena pajak daerah merupakan bagian dari pendapatan asli daerah yang terbesar. Dana Alokasi Khusus tidak berpengaruh secara signifikan terhadap alokasi belanja daerah, karena kebutuhan sulit diperkirakan dengan rumus alokasi umum dan kebutuhan merupakan komitmen atau prioritas nasional. Pajak daerah dan dana alokasi khusus secara simultan berpengaruh secara positif dan signifikan terhadap alokasi belanja daerah.
\end{abstract}

Kata Kunci: Pajak Daerah, Dana Alokasi Khusus, Belanja Daerah.

\begin{abstract}
This study aims to provide empirical evidence of the influence of regionall taxes and the specific allocation fund for regional expense Madiun district. The types of data used in this study is primary data consisting of regents rules, report revenues in the Specific Allocation Fund report in and report the realization of the state budget. The method used in this research is a quantitative research method using multiple linear regression analysis technique and test hypotheses processed with SPSS. The results of the data analysis showed that the regional tax has a positive and significant impact on the allocation of regional expense as part of the biggest revenue. Specific Allocation Fund does not significantly affect the allocation of regional expense, because the need is difficult to estimate the general allocation formula and the need for a commitment or a national priority. Regional taxes and specificl allocation funds simultaneously have a positive and significant impact on the allocation of regional expense.
\end{abstract}

Keyword: regional taxes, specific allocation fund, allocation of regional expense.

\section{PENDAHULUAN}

Undang-Undang No.32 Tahun 2004 menitikberatkan otonomi pada daerah Kabupaten dan Kota dengan tujuan agar daerah yang bersangkutan memiliki otonomi dan mengatur perimbangan keuangan Antara Pemerintah Pusat dan Daerah. Pembiayaan penyelenggaraan pemerintah berdasarkan asas desentralisasi di lakukan atas beban APBD. Sumber dana bagi daerah terdiri dari Pendapatan Asli Daerah (PAD) yang meliputi pajak daerah dan retribusi daerah, Dana Perimbangan (DBH, DAU, dan DAK) dan Pinjaman 
daerah. Menurut Suparmoko (2002:55) pajak daerah merupakan bagian pendapatan asli daerah yang terbesar, kemudian diikuti dengan pendapatan yang berasal dari retribusi daerah. Pajak daerah yaitu iuran wajib yang dilakukan oleh orang pribadi atau badan kepada pemerintah (daerah) tanpa balas jasa langsung yang dapat ditunjuk, yang dapat dipaksakan berdasarkan peraturan perundang-undangan yang berlaku. Penerimaan dari pajak ini digunakan untuk membiayai penyelenggaraan pemerintah dan pembangunan daerah.

Dana Alokasi Khusus (DAK) adalah dana yang berasal dari APBN, yang dialokasikan kepada Daerah untuk membantu membiayai kebutuhan tertentu (UU No. 33 Tahun 2004). Pemerolehan dan pemanfaatan Dana Alokasi Khusus (DAK) harus mengikuti rambu-rambu yang telah ditetapkan oleh Pemerintah Pusat. DAK dialokasikan dalam APBN untuk daerah-daerah tertentu dalam rangka mendanai kegiatan khusus yang merupakan urusan daerah dan termasuk dalam program prioritas nasional. Daerah dapat menerima DAK apabila memenuhi tiga kriteria, yaitu (1) kriteria umum berdasarkan indeks fiskal neto; (2) kriteria khusus berdasarkan peraturan perundangan dan karakteristik daerah; dan (3) kriteria teknis berdasarkan indeks teknis bidang terkait (UU No. 32/2004 dan UU No. 33/2004).

Daerah penerima DAK wajib menyediakan dana pendamping dalam APBD minimal $10 \%$ dari DAK yang diterima. Pengecualian dapat diberikan kepada daerah dengan kemampuan fiskal rendah. Selain itu, daerah diwajibkan menyediakan 3\% dari nilai DAK yang diterima untuk biaya umum yang diambil dari sumber penerimaan lainnya. DAK dipakai untuk menutup kesenjangan pelayanan publik antar daerah dengan prioritas pada bidang pendidikan, kesehatan, infrastruktur, kelautan dan perikanan, pertanian, prasarana pemerintahan daerah, dan lingkungan hidup.

\section{TELAAH LITERATUR}

\section{Alokasi Belanja Daerah}

Afiah (2009:15) belanja daerah meliputi semua pengeluaran dari rekening kas umum dan daerah yang mengurangi ekuitas dana, merupakan kewajiban daerah dalam satu tahun anggaran dan tidak akan diperoleh pembayarannya kembali oleh daerah.

Halim (2004:70) belanja daerah adalah semua pengeluaran Pemerintah Daerah pada suatu periode Anggaran. Anggaran Pendapatan dan Belanja Daerah terdiri dari tiga komponen utama, yaitu unsur penerimaan, belanja rutin dan belanja pembangunan. Ketiga komponen itu meskipun disusun hampir secara bersamaan, akan tetapi proses penyusunannya berada di lembaga yang berbeda.

Dari beberapa uraian tentang pengertian belanja daerah di atas peneliti dapat menyimpulkan bahwa belanja daerah adalah pembiayaan yang dikeluarkan pemerintah daerah untuk membiayai pembangunan dan pembelanjaan daerah.

a. Pengertian anggaran

Bahtiar (2002:14) anggaran merupakan satu instrumen penting di dalam manajemen karena merupakan bagian dari fungsi manajemen. Di dunia bisnis maupun di kegiatan organisasi sektor publik, termasuk pemerintah, anggaran merupakan bagian dari aktivitas penting yang dilakukan secara rutin.

Darise (2008:133) anggaran pemerintah merupakan dokumen formal hasil kesepakatan antara eksekutif dan legislatif tentang belanja yang ditetapkan untuk melaksanakan kegiatan pemerintah dan pendapatan yang diharapkan untuk menutup keperluan belanja tersebut atau pembiayaan yang diperlukan bila diperkirakan akan terjadi defisit dan surplus. 
Berdasarkan pernyataan diatas, definisi anggaran dapat diringkas menjadi, sebagai berikut:

1) Rencana keuangan mendatang yang berisi pendapatan dan belanja

2) Gambaran strategi pemerintah dalam pengalokasian sumber daya untuk pembangunan

3) Alat pengendalian

4) Disusun dalam periode tertentu

Darise (2008:133) fungsi anggaran di lingkungan pemerintah mempunyai pengaruh penting dalam akuntansi dan pelaporan keuangan, antara lain karena :

1) Anggaran merupakan pernyataan kebijakan publik.

2) Anggaran merupakan target fiskal yang menggambarkan keseimbangan antara belanja, pendapatan, dan pembiayaan yang diinginkan.

3) Anggaran menjadi landasan pengendalian yang memiliki konsekuensi hukum.

4) Anggaran memberi landasan penilaian kinerja pemerintan.

5) Hasil pelaksanaan anggaran dituangkan dalam laporan keuangan pemerintah sebagai pertanggungjawaban pemerintah kepada publik.

\section{Struktur APBD}

Darise (2008:133-134) APBD merupakan satu kesatuan yang terdiri dari:

a. Pendapatan daerah. Belanja daerah dan pembiayaan daerah.

Selisih antara anggaran pendapatan daerah dengan anggaran belanja daerah mengakibatkan terjadinya surplus atau defisit APBD. Surplus anggaran, terjadi apabila anggaran pendapatan daerah diperkirakan lebih besar dari anggaran belanja daerah. Defisit anggaran terjadi apabila anggaran pendapatan daerah diperkirakan lebih kecil dari anggaran belanja daerah.

Dalam hal APBD diperkirakan surplus, digunakan/dimanfaatkan untuk pembayaran pokok utang, penyertaan modal (investasi) daerah, pemberian pinjaman kepada pemerintah pusat/daerah, transfer ke dana cadangan dan sisa lebih tahun anggaran berjalan. Pemanfaatan surplus disebut pengeluaran pembiayaan.

Dalam hal APBD diperkirakan defisit, ditetapkan pembiayaan untuk menutup defisit tersebut diantaranya bersumber dari usia lebih perhituungan anggaran lalu, penggunaan dana cadangan, penerimaan pinjaman, hasil penjualan kekayaan daerah yang dipisahkan, dan penerimaan kembali pemberian pinjaman atau penerimaan piutang. Langkah-langkah untuk menutupi defisit disebut penerimaan pembiayaan.

b. Klasifikasi Belanja Daerah

Darise (2008:138-141) Belanja Daerah diklasifikasikan menurut:

1) Fungsi

Klasifikasi menurut fungsi adalah klasifikasi yang didasarkan pada fungsi-fungsi utama pemerintah daerah dalam memberikan pelayanan kepada masyarakat.

2) Organisasi

Yang dimaksud dengan klasifikassi belanja menurut organisasi pemerintahan daerah seperti Kepala Daerah dan Wakil Kepala Daerah, Sekretariat Daerah, Sekretariat DPRD, Dinas, Badan, Lembaga Teknis Daerah, Kecamatan dan Kelurahan.

3) Kelompok Belanja dan Jenis Belanja

Belanja pada setiap satuan kerja perangkat daerah (SKPD) diklasifikasikan berdasarkan kelompok belanja yaitu: belanja langsung, belanja pegawai, belanja barang dan jasa, belanja modal, belanja tidak langsung. Perundangan yang mengatur 
Alokasi Belanja Daerah adalah Undang-Undang Republik Indonesia Nomor 33 Tahun Pajak Daerah

2004 pada pasal 66, pasal 67 dan pasal 68.

Menurut Suparmoko (2002:60) pajak daerah adalah iuran wajib pajak yang dilakukan oleh orang atau badan kepada daerah tanpa imbalan langsung yang seimbang, yang dapat dipaksakan berdasarkan peraturan perundang-undangan yang berlaku, yang digunakan untuk membiayai penyelenggeraan pemerintahan daerah dan pembangunan daerah.

Darise (2008:135-136) pajak daerah adalah iuran wajib yang dilakukan oleh orang atau pribadi atau badan kepada daerah tanpa imbalan langsung yang seimbang yang dapat dilaksanakan berdasarkan Peraturan Perundang-undangan yang berlaku digunakan untuk membiayai penyelenggaraan pemerintah daerah dan pembangunan daerah.

\section{Dana Alokasi Khusus}

Perundangan yang mengatur Dana Alokasi Khusus adalah Undang-Undang Republik Indonesia Nomor 33 Tahun 2004 pasal 39, pasal 40 dan pasal 41. Menurut Suparmoko (2002:43) dana alokasi khusus berasal dari APBN dan dialokasikan ke kabupaten/kota untuk membiayai kebutuhan tertentu yang sifatnya khusus, tergantung pada tersedianya dana dalam APBN. Yang dimaksud dengan kebutuhan khusus adalah kebutuhan yang sulit diperkirakan dengan rumus alokasi umum, dan/atau kebutuhan yang merupakan komitmen atau prioritas nasional.

Dana Alokasi Khusus (DAK) adalah dana yang berasal dari APBN, yang dialokasikan kepada Daerah untuk membantu membiayai kebutuhan tertentu (UU No. 33 Tahun 2004). Dana alokasi khusus digunakan untuk menutup kesenjangan pelayanan publik antar daerah dengan memberi prioritas pada bidang pendidikan, kesehatan, infrastruktur, kelautan dan perikanan, pertanian, prasarana pemerintahan daerah, dan lingkungan hidup.

Darise (2008:137-138) DAK dimaksudkan untuk membantu membiayai kegiatankegiatan khusus di daerah tertentu yang merupakan urusan daerah dan sesuai dengan prioritas nasional, khususnya untuk membiayai kebutuhan sarana dan prasarana pelayanan dasar masyarakat yang belum mencapai standar tertentu atau untuk mendorong percepatan pembangunan daerah.

Penelitian serupa dilakukan oleh Bambang Prakosa (2004) di wilayah DIY dan Jateng memperoleh hasil PAD dan DAU berpengaruh signifikan terhadap Belanja Daerah. Soeratno (2005-2009) memperoleh hasil yaitu bahwa secara simultan Pendapatan Asli Daerah (PAD), Dana Alokasi Umum (DAU), dan Dana Alokasi Khusus (DAK) berimplikasi secara signifikan terhadap belanja daerah. Hal ini berarti semakin besar pendapatan asli daerah, dana alokasi umum, dan dana alokasi khusus sebagai sumber penerimaan daerah maka semakin besar dana yang dikeluarkan untuk belanja daerah pada kabupaten/kota di Jawa Barat. Kusnandar, Dodik Siswantoro dari Laporan Hasil Pemeriksaan Badan Pemeriksa Keuangan tahun 2011 (LHP-BPK 2011) secara empiris penelitian ini membuktikan bahwa besarnya alokasi belanja modal dipengaruhi oleh DAU, PAD, SiLPA dan luas wilayah. Secara parsial DAU tidak berpengaruh terhadap alokasi belanja modal sedangkan PAD, SiLPA dan Luas Wilayah berpengaruh. Diah Sulistyowati yang meneliti Kabupaten/Kota di Bali (2011) memperoleh hasil yaitu Pajak Daerah, Retribusi Daerah, dan Dana Alokasi Umum berpengaruh positif terhadap alokasi Belanja Modal. Sedangkan Dana Alokasi Khusus berpengaruh negatif terhadap alokasi Belanja Modal. 


\title{
KERANGKA BERFIKIR DAN PENGEMBANGAN HIPOTESIS
}

\author{
Gambar 1
}

Skema Kerangka Berfikir

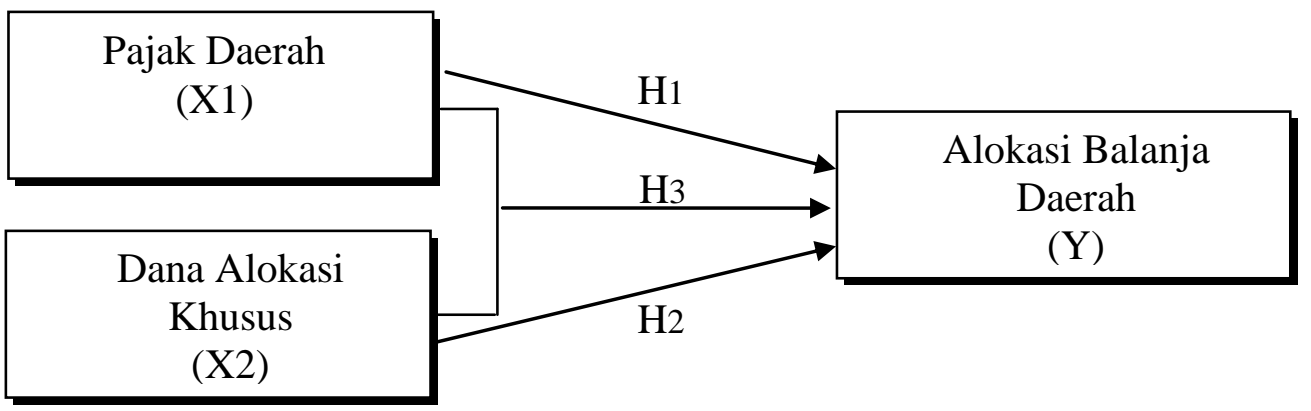

Berdasarkan skema kerangka berfikir diatas, terdapat tiga variabel, yaitu dua variabel bebas (independent) atau $\mathrm{X}_{1}$ dan $\mathrm{X}_{2}$ dan variabel terikat (dependent) atau $\mathrm{Y}$. Variabel bebas berupa pajak daerah dan dana alokasi khusus sedangkan variabel terikat berupa belanja daerah. Penelitian ini bertujuan untuk mengetahui pengaruh pajak daerah dan dana alokasi khusus terhadap alokasi belanja daerah.

\section{Hipotesis Penelitian}

Hipotesis dalam penelitian ini adalah sebagai berikut:

$\mathrm{H}_{1}$ = Pajak daerah berpengaruh secara signifikan terhadap alokasi belanja daerah Kabupaten Madiun

$\mathrm{H}_{2}=$ Dana alokasi khusus berpengaruh secara signifikan terhadap alokasi belanja daerah Kabupaten Madiun

$\mathrm{H}_{3}$ = Pajak daerah dan dana alokasi khusus berpengaruh secara signifikan terhadap alokasi belanja daerah Kabupaten Madiun

\section{METODOLOGI PENELITIAN}

Penelitian ini dilakukan di Kabupaten Madiun. Penelitian ini menggunakan metode penelitian kuantitatif. Sumber data menggunakan data primer sebagai berikut:(1)Peraturan Bupati, (2) Laporan Pendapatan Asli Daerah,(3) Laporan Dana Alokasi Khusus, (4)Laporan Realisasi Anggaran Belanja daerah

\section{Definisi Operasional}

1. Variabel Alokasi Belanja Daerah (Y)

Belanja daerah adalah pembiayaan yang dikeluarkan pemerintah daerah untuk membiayai pembangunan dan pembelanjaan daerah.

2. Variabel Pajak Daerah $\left(\mathrm{X}_{1}\right)$

Pajak daerah adalah pembayaran berupa uang yang dilakukan oleh perseorangan atau badan dimana tarif pajak ditentukan oleh peraturan pemerintah daerah dan untuk membiayai penyelenggaraan pemerintah.

3. Variabel Dana Alokasi Khusus $\left(\mathrm{X}_{2}\right)$

Dana alokai khusus adalah sejumlah dana berasal dari APBN yang dialokasikan ke kabupaten/kota untuk membiayai kebutuhan tertentu yang sifatnya khusus, tergantung pada tersedianya dana dalam APBN. 


\section{ANALISIS DATA}

Analisis data menggunakan program SPSS (Statistical Package for the Social Science) for windows versi 17.0. dengan tahap-tahap analisis sebagai berikut :

a. Uji Normalitas

Uji normalitas digunakan untuk mengetahui apakah data terdistribusi dengan normal atau tidak. Analisis parametik seperti regresi linier mensyaratkan bahwa data harus terdistribusi dengan normal (Duwi Priyatno, 2010:54).

b. Uji Asumsi Klasik

Pengujian regresi linier berganda dapat dilakukan setelah model dari penelitian ini memenuhi syarat-syarat yaitu lolos dari asumsi klasik. Syarat-syarat yang harus dipenuhi adalah data tersebut harus terdistribusikan secara normal, tidak mengandung multikoloniaritas, dan heterokedastisitas. Untuk itu sebelum melakukan pengujian regresi linier berganda perlu dilakukan lebih dahulu pengujian asumsi klasik, yang terdiri dari:

\section{1). Multikolinearitas}

Multikolinearitas adalah keadaan dimana antara dua variabel independen atau lebih pada model regresi terjadi hubungan linier yang sempurna atau mendekati sempurna. Model regresi yang baik mensyaratkan tidak adanya masalah multikolinearitas (Priyatno, 2010:62).

2). Heteroskedastisitas

Heteroskedastisitas adalah keadaan dimana terjadinya ketidaksamaan varian dan residual pada model regresi. Model regresi yang baik mensyaratkan tidak adanya masalah heteroskedastisitas (Priyatno, 2010:67)

3). Autokorelasi

Menurut Priyatno (2010:75), autokorelasi adalah keadaan dimana terjadinya korelasi secara residual untuk engamatan satu dengan pengamatan yang lain yang disusun menurut runtut waktu. Model regresi yang baik mensyaratkan tidak adanya masalah autokorelasi dengan menggunakan uji Durbin-Watson (DW test).

c. Analisis Regresi Linier Berganda

Menurut Sugiono (2010: 275) rumus regresi linier berganda adalah :

$\mathrm{Y}=\alpha+\mathrm{b}_{1} \mathrm{X}_{1}+\mathrm{b}_{2} \mathrm{X}_{2}$

Dimana :

$\mathrm{Y}=$ Alokasi Belanja Daerah

$\alpha=$ konstanta

$\mathrm{b}_{(1,2)}=$ koefisien regresi $\mathrm{X}_{(1,2)}$ terhadap $\mathrm{Y}$

$\mathrm{X} 1$ = Pajak Daerah

$\mathrm{X} 2$ = Dana Alokasi Khusus

d. Pengujian Hipotesis

1). Uji t

Uji t digunakan untuk menguji pegaruh variabel independen secara parsial terhadap variabel dependen.

Langkah-langkah uji t sebagai berikut:

Pengujian Koefisien regresi variabel Pajak Daerah $\left(\mathrm{X}_{1}\right)$

1. $\quad$ Ho $=$ Pajak Daerah secara parsial tidak berpengaruh terhadap Alokasi Belanja Daerah 
2. $\mathrm{Ha}=$ Pajak Daerah secara parsial berpengaruh terhadap Alokasi Belanja Daerah

3. Tingkat signifikansinya 0,05

4. Penentuan kriteria penerimaan dan penolakan:

Ho diterima jika: $\mathrm{t}_{\text {hitung }}<\mathrm{t}$ tabel

Ho ditolak jika : $\mathrm{t}_{\text {hitung }}>\mathrm{t}$ tabel

Pengujian koefisien korelasi variabel Dana Alokasi Khusus $\left(\mathrm{X}_{2}\right)$

1. Ho = Dana Alokasi Khusus secara parsial tidak berpengaruh terhadap Alokasi Belanja Daerah

2. $\mathrm{Ha}=$ Dana Alokasi Khusus secara parsial berpengaruh terhadap Alokasi Belanja Daerah

3. Tingkat signifikansinya 0,05

4. Penentuan kriteria penerimaan dan penolakan:

Ho diterima jika: $\mathrm{t}_{\text {hitung }}<\mathrm{t}$ tabel

Ho ditolak jika: $\mathrm{t}_{\text {hitung }}>\mathrm{t}$ tabel

2). Uji F

Langkah-langkah uji F sebagai berikut:

1. Ho = Pajak Daerah dan Dana Alokasi Khusus tidak berpengaruh terhadap Alokasi Belanja Daerah

2. $\mathrm{Ha}=$ Pajak Daerah dan Dana Alokasi Khusus secara bersama-sama berpengaruh terhadap Alokasi Belanja Daerah.

3. Tingkat signifikansinya 0,05

4. Penentuan kriteria penerimaan dan penolakan:

Ho diterima jika : $\mathrm{F}_{\text {hitung }}<\mathrm{F}$ tabel atau nilai probabilitas $>5 \%$

Ho ditolak jika : $\mathrm{F}_{\text {hitung }}>\mathrm{F}$ tabel atau nilai probabilitas $<5 \%$

\section{PEMBAHASAN}

Hasil Pengujian Hipotesis

Tujuan penelitian ini adalah untuk mengetahui pengaruh pajak daerah dan dana alokasi khusus terhadap alokasi belanja daerah di Kabupaten Madiun Tahun 2003 sampai dengan Tahun 2010. Hipotesis dalam penelitian ini adalah sebagai berikut:

$\mathrm{H}_{1}=$ Pajak daerah berpengaruh secara signifikan terhadap alokasi belanja daerah Kabupaten Madiun.

$\mathrm{H}_{2}=$ Dana alokasi khusus berpengaruh secara signifikan terhadap alokasi belanja daerah Kabupaten Madiun

$\mathrm{H}_{3}=$ Pajak daerah dan dana alokasi khusus berpengaruh secara signifikan terhadap alokassi belanja daerah Kabupaten Madiun

Uji Normalitas dan Uji Asumsi Klasik

1. Uji Normalitas

Uji normalitas digunakan untuk mengetahui apakah data terdistribusi secara normal atau tidak. Berdasarkan hasil analisis dengan menggunakan program SPSS (Statistical Package for the Social Science) for windows versi 17.0. Maka diperoleh hasil sebagai berikut: 
Gambar 2

Uji Normalitas

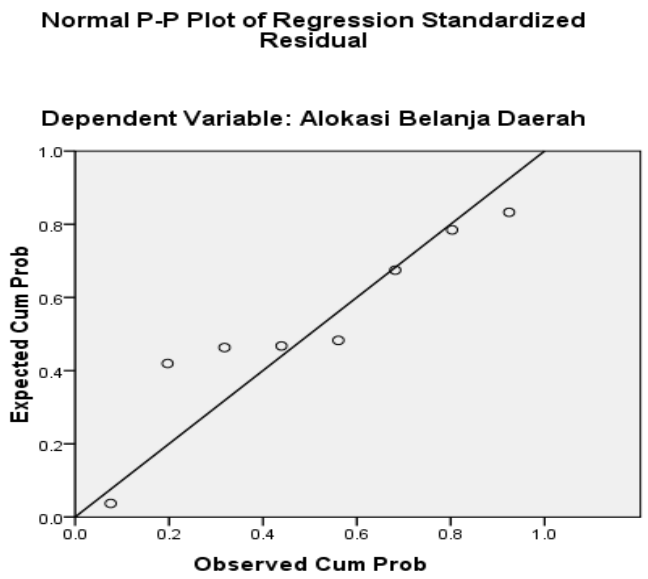

Sumber: Data yang diolah

Berdasarkan keterangan grafik diatas, titik menyebar disekitar garis diagonal dan mengikuti arah garis diagonal, maka data terdistribusi normal sehingga model regresi memenuhi asumsi normalitas.

Dari hasil uji normalitas dengan menggunakan metode Normal Probability Plots, maka dapat dilihat bahwa titik-titik penyebaran data mengikuti disekitar garis diagonal, maka dapat dinyatakan data terdistribusi normal sehingga model regresi memenuhi asumsi normal.

2. Hasil Pengujian Asumsi Klasik

a. Multikolinearitas

Multikolinearitas adalah keadaan dimana antara dua variabel independen atau lebih pada model regresi terjadi hubungan linier yang sempurna atau mendekati sempurna. Model regresi yang baik mensyaratkan tidak adanya masalah multikolinearitas (Priyatno, 2010:62).

Uji multikolinearitas dilakukan dengan uji VIF. JIka VIF masing-masing variabel lebih besar dari 10 atau tidak. Apabila nilai VIF lebih besar dari 10 maka diindikasikan model tersebut memiliki gejala Multikolinearitas (Priyatno, 2010:67). Hasil uji multikolinearitas pada tabel berikut:

Tabel 1

Hasil Uji Multikolinearitas

\begin{tabular}{lcccccccc}
\hline \multirow{2}{*}{ Model } & \multicolumn{2}{c}{$\begin{array}{c}\text { Unstandardized } \\
\text { Coefficients }\end{array}$} & \multicolumn{2}{c}{$\begin{array}{c}\text { Standardized } \\
\text { Coefficients }\end{array}$} & \multicolumn{4}{c}{$\begin{array}{c}\text { Collinearity } \\
\text { Statistics }\end{array}$} \\
\cline { 2 - 9 } & B & Std. Error & Beta & T & Sig. & Tolerance & VIF \\
\hline (Constant) & $-2.202 \mathrm{E} 11$ & $1.856 \mathrm{E} 11$ & & -1.187 & .289 & & \\
Pajak Daerah & 106.209 & 38.192 & .690 & 2.781 & .039 & .428 & 2.339 \\
DAK & 2.228 & 1.887 & .293 & 1.181 & .291 & .428 & 2.339 \\
\hline
\end{tabular}

a. Dependent Variable: Alokasi Belanja Daerah

Sumber: Data yang diolah 
Berdasarkan tabel tersebut di atas terlihat bahwa seluruh variabel independen yaitu pajak daerah dan dana alokasi khusus memiliki angka Variance Inflation Factors (VIF) di bawah 10 dengan angka tolerance yang menunjukkan nilai lebih dari 0,10 . Dengan demikian dapat dikatakan bahwa model yang terbentuk tidak terdapat adanya gejala multikolinearitas antar variabel independen dalam regresi.

b. Heteroskedastisitas

Uji heteroskedastisitas dilakukan dengan melakukan pengamatan terhadap scatterplot dari pengujian data dengan SPSS for windows versi 17.0. Apabila pada scatterplot titik-titik menyebar diatas dan dibawah angka 0 pada sumbu Y maka pola tersebut tidak terjadi heteroskedastisitas (Priyatno, 2010:74).

\section{Gambar 3}

Uji Heteroskedastisitas

Scatterplot

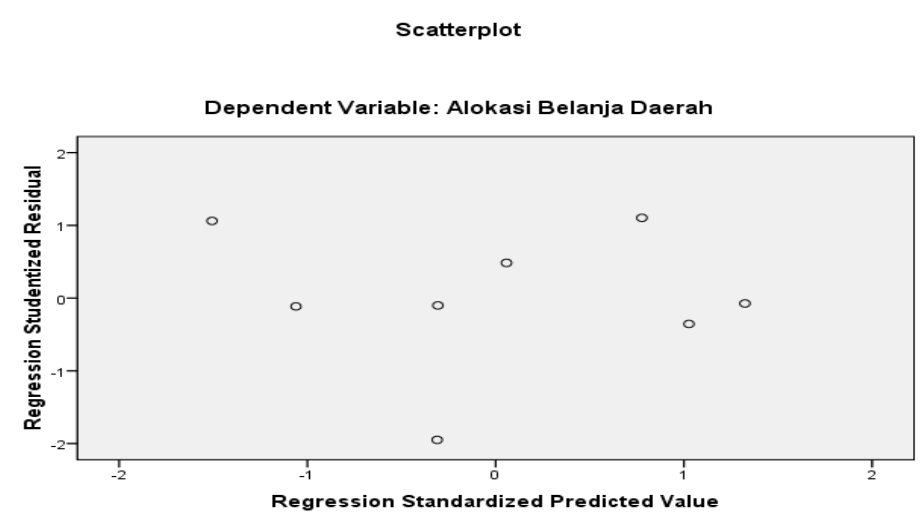

Sumber: Data yang diolah

Berdasarkan grafik scatterplot terlihat titik menyebar secara acak, tidak membentuk sebuah pola terrtentu yang jelas atau teratur, serta titik terbesar di atas dan di bawah angka 0 dan sumbu Y. Dengan demikian dapat dikatakan bahwa tidak terjadi gejala heteroskedastisitas pada model regresi.

c. Autokorelasi

Berdasarkan hasil analisis dengan menggunakan program SPSS (Statistical Package for the Social Science) for windows versi 17.0. Diperoleh hasil sebagai berikut:

Tabel 2

Hasil Uji Autokorelasi

\begin{tabular}{cccccc}
\hline Model & $\mathrm{R}$ & $\mathrm{R}$ Square & $\begin{array}{c}\text { Adjusted } \mathrm{R} \\
\text { Square }\end{array}$ & $\begin{array}{c}\text { Std. Error of the } \\
\text { Estimate }\end{array}$ & Durbin Watson \\
\hline 1 & $.932^{\mathrm{a}}$ & .868 & .816 & $7.80220 \mathrm{E} 10$ & 1.927
\end{tabular}

a. Predictors: (Constant), DAK, Pajak Daerah

b. Dependent Variable: Alokasi Belanja Daerah

Sumber: Data yang diolah 
Berdasarkan tabel diatas menunjukkan nilai DW sebesar 1,927. Dengan jumlah variabel bebas $(\mathrm{k})=2$, dengan jumlah $(\mathrm{n})=8$, maka $\mathrm{dL}=0,559$ dan $\mathrm{dU}=1,777$, jadi dapat dihitung $4-\mathrm{dL}=3,441$ dan $4-\mathrm{dU}=2,223$. Nilai DW sebesar 1,927 terletak antara dU dan $4-\mathrm{dU}$ maka dapat disimpulkan model regresi linier berganda terbebas dari autokorelasi.

3. Hasil Analisis Regresi Linier Berganda

Berdasarkan hasil analisis dengan menggunakan program SPSS (Statistical Package for the Social Science) for windows versi 17.0. Maka diperoleh hasil sebagai berikut:

Tabel 3

Hasil Analisis Regresi Linier Berganda dan Hasil Uji t

Coefficients $^{\mathrm{a}}$

\begin{tabular}{ccccccccc}
\hline & \multicolumn{2}{c}{$\begin{array}{c}\text { Unstandardized } \\
\text { Coefficients }\end{array}$} & \multicolumn{2}{c}{$\begin{array}{c}\text { Standardized } \\
\text { Coefficients }\end{array}$} & \multicolumn{4}{c}{$\begin{array}{c}\text { Collinearity } \\
\text { Statistics }\end{array}$} \\
\cline { 2 - 9 } Model & \multicolumn{1}{c}{ B } & Std. Error & Beta & T & Sig. & Tolerance & VIF \\
\hline 1 (Constant) & $-2.202 \mathrm{E} 11$ & $1.856 \mathrm{E} 11$ & & -1.187 & .289 & & \\
Pajak Daerah & 106.209 & 38.192 & .690 & 2.781 & .039 & .428 & 2.339 \\
DAK & 2.228 & 1.887 & .293 & 1.181 & .291 & .428 & 2.339 \\
\hline
\end{tabular}

a. Dependent Variable: Alokasi Belanja Daerah

Sumber: Data yang diolah

$\mathrm{Y}=-220.200 .000 .000+106,209 \mathrm{X}_{1}+2{ }^{2} 228 \mathrm{X}_{2}$

4. Pengujian Hipotesis

1. Uji t

Berdasarkan perhitungan SPSS for windows versi 17.0 diperoleh hasil uji t pada tabel 4.3, yang dapat dijelaskan sebagai berikut:

1) Pengaruh pajak daerah terhadap alokasi belanja daerah

Pada variabel pajak daerah diperoleh koefisien regresi sebesar 106,209. Uji keberartian koefesien regresi dengan uji $\mathrm{t}_{\text {hitung }}=2,781$ dengan signifikansi

0,039. Karena harga signifikansi yang diperoleh lebih kecil dari 0,05 maka pajak daerah secara parsial berpengaruh secara signifikan terhadap alokasi belanja daerah Kabupaten Madiun.

2) Pengaruh dana alokasi khusus terhadap alokasi belanja daerah

Pada variabel dana alokasi khusus diperoleh koefisiensi regresi sebesar 2,228. Uji keberartian koefisien regresi dengan uji $\mathrm{t}$ diperoleh $\mathrm{t}_{\text {hitung }}=1,181$ dengan signifikansi 0,291 . Karena harga signifikansi yang diperoleh lebih besar dari 0,05 maka secara parsial dana alokasi khusutidak berpengaruh terhadap alokasi belanja daerah di Kabupaten Madiun.

2. Uji F

Uji F digunakan untuk menguji pengaruh semua variabel independen yaitu pajak daerah $\left(\mathrm{X}_{1}\right)$, dana alokasi khusus $\left(\mathrm{X}_{2}\right)$ secara bersama-sama terhadap variabel dependen yaitu alokasi belanja daerah (Y). Berdasarkan perhitungan SPSS for windows versi 17.0 diperoleh hasil untuk uji F sebagai berikut: 
Tabel 4

Hasil Uji F

\begin{tabular}{lccccc}
\hline Model & Sum of Squares & Df & Mean Square & F & Sig. \\
\hline Regression & $2.007 \mathrm{E} 23$ & 2 & $1.003 \mathrm{E} 23$ & 16.484 & $.006^{\mathrm{a}}$ \\
Residual & $3.044 \mathrm{E} 22$ & 5 & $6.087 \mathrm{E} 21$ & & \\
Total & $2.311 \mathrm{E} 23$ & 7 & & & \\
\hline
\end{tabular}

a. Predictors: (Constant), DAK, Pajak Daerah

b. Dependent Variable: Alokasi Belanja Daerah

Sumber: Data yang diolah

Hasil $\mathrm{F}_{\text {hitung }}=16,484$ dengan signifikansi sebesar 0,006. menunjukkan bahwa nilai $\mathrm{F}_{\text {hitung }}$ yang diperoleh tersebut signifikan. Artinya pajak daerah dan dana alokasi khusus secara simultan mempengaruhi alokasi belanja daerah di Kabupaten Madiun

\section{KESIMPULAN}

1. Pajak daerah berpengaruh secara positif dan signifikan terhadap alokasi belanja daerah karena pajak daerah merupakan bagian pendapatan asli daerah terbesar. Sehingga semakin tinggi nilai pajak daerah maka semakin tinggi nilai belanja daerah yang harus dikeluarkan oleh Pemerintah Daerah dan sebaliknya.

2. Dana Alokasi Khusus tidak berpengaruh positif terhadap alokasi belanja daerah, karena kebutuhan sulit diperkirakan dengan rumus alokasi umum dan kebutuhan merupakan komitmen atau prioritas nasional. Namun pemerintah daerah yang menerima DAK wajib menyediakan Dana Pendamping sekurang-kurangnya $10 \%$ dari nilai DAK yang diterimanya untuk mendanai kegiatan fisik. Dana Pendamping tersebut wajib dianggarkan dalam APBD tahun anggaran berjalan.

3. Pajak Daerah dan Dana Alokasi Khusus secara simultan berpengaruh secara positif dan signifikan terhadap Alokasi Belanja Daerah. Jika variabel pajak daerah dan dana alokasi khusus ditingkatkan, maka akan diikuti dengan meningkatnya alokasi belanja daerah dan sebaliknya.

\section{Saran}

1. Alokasi belanja daerah dapat terus ditingkatkan dengan cara menggali sumber-sumber pendapatan asli daerah yang salah satunya yaitu pajak daerah. Meningkatkan kinerja Dinas Pendapatan Daerah dengan cara optimalisasi pengelolaan pajak.

2. Optimalisasi pengelolaan Dana Alokasi Khusus dengan cara memaksimalkan DAK kriteria umum, kriteria khusus, dan kriteria teknis. Sehingga akan menjadi perhatian Pemerintah Pusat dalam memberikan DAK yang memadai untuk mendorong percepatan pembangunan daerah.

3. Penelitian ini belum mencakup aspek-aspek lain yang mungkin merupakan faktor penting, misalnya aspek kebijakan publik, aspek manajemen keuangan dan aspek penganggaran daerah, untuk itu disarankan bagi peneliti selanjutnya bisa memperluas area penelitian pada tataran praktis.

\section{DAFTAR PUSTAKA}

Afiah, Nur, Nunuy. 2009. Akuntansi Pemerintahan: Implementasi Akuntansi Keuangan Pemerintah Daerah. Jakarta: Predana Media Group

Bahtiar, Arif. 2002. Akuntansi Pemerintahan. Jakarta: Salemba Empat 
Halim, Abdul. 2007. Akuntansi Sektor Publik: Akuntansi Keuangan Daerah. Jakarta: Salemba Empat

Iqbal, Hasan. 2010. Analisis Data Penelitian Dengan Statistik . Jakarta: PT Bumi Aksara

Kesit, Bambang, Prakosa. 2004. Analisis Pengaruh Dana Alokasi Umum (DAU) Dan Pendapatan Asli Daerah (PAD) Terhadap Prediksi Belanja Daerah. Studi Empirik di Wilayah Propinsi Jawa Tengah dan DIY.

Kusnandar dan Dodik Siswantoro. 2011. Pengaruh Dana Alokasi Umum, Pendapatan Asli Daerah, Sisa Lebih Pembiayaan Anggaran Dan Luas Wilayah Terhadap Belanja Modal. Universitas Indonesia.

Lembaran Negara Republik Indonesia. Undang-undang Nomor 32 Tahun 2004 tentang Pemerintah Daerah

Lembaran Negara Republik Indonesia. Undang-undang Nomor 33 Tahun 2004 tentang Perimbangan Keuangan Pemerintah Pusat dan Daerah.

Nurlan, Darise. 2008. Akuntansi Keuangan Daerah. Jakarta: PT Indeks

Priyatno, Duwi. 2010. Tehnik Mudah dan Cepat Melakukan Analisis Data Penelitian dengan SPSS. Yogyakarta: Gava Media

Resmi, Siti. 2011. Perpajakan: Teori dan Kasus. Jakarta: Salemba Empat

Sugiono. 2010. Statistik untuk Penelitian. Bandung: CV Alfabeta

Sulistyowati, Diah. 2011. Pengaruh Pajak Daerah, Retribusi Daerah, Dana Alokasi Umum, dan Dana Alokasi Khusus Terhadap Alokasi Belanja Daerah. Skripsi Sarjana (dipublikasikan). Fakultas Ekonomi Universitas Diponegoro Semarang.

Suparmoko. 2002. Ekonomi Publik untuk keuangan dan pembangunan daerah. Yogyakarta: ANDI

Soeratno. Analisis Faktor-faktor Pendapatan Dominan Dan Implikasinya Terhadap Anggaran Belanja Daerah. Studi empiris pada pemerintah kabupaten/kota di Provinsi Jawa Barat periode 2005-2009. Fakultas Ekonomi Universitas Esa Unggul Jakarta. 